AFTER THE COLD WAR 
Also by Arthur I. Cyr

* BRITISH FOREIGN POLICY AND THE ATLANTIC AREA The Techniques of Accommodation

LIBERAL POLITICS IN BRITAIN

* US FOREIGN POLICY AND EUROPEAN SECURITY

* From the same publishers 


\section{After the Cold War}

American Foreign Policy, Europe and Asia

Arthur I. Cyr

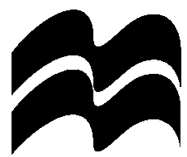


C Arthur I. Cyr 1997, 2000

Softcover reprint of the hardcover 1st edition 2000 978-0-333-67211-2

All rights reserved. No reproduction, copy or transmission of this publication may be made without written permission.

No paragraph of this publication may be reproduced, copied or transmitted save with written permission or in accordance with the provisions of the Copyright, Designs and Patents Act 1988, or under the terms of any licence permitting limited copying issued by the Copyright Licensing Agency, 90 Tottenham Court Road, London W1P 0LP.

Any person who does any unauthorised act in relation to this publication may be liable to criminal prosecution and civil claims for damages.

The author has asserted his right to be identified as the author of this work in accordance with the Copyright, Designs and Patents Act 1988.

Published 2000 by

MACMILLAN PRESS LTD

Houndmills, Basingstoke, Hampshire RG21 6XS

and London

Companies and representatives

throughout the world

First edition 1997

Reprinted (with new Preface and Epilogue) 2000

ISBN 978-1-349-14239-2

ISBN 978-0-333-97748-4 (eBook)

DOI $10.1057 / 9780333977484$

A catalogue record for this book is available from the British Library.

This book is printed on paper suitable for recycling and made from fully managed and sustained forest sources.

$\begin{array}{rrrrrrrrrr}10 & 9 & 8 & 7 & 6 & 5 & 4 & 3 & 2 & 1 \\ 09 & 08 & 07 & 06 & 05 & 04 & 03 & 02 & 01 & 00\end{array}$


To the memory of my father

Irving A. Cyr 
This page intentionally left blank 


\section{Contents}

Preface to the 2000 Reprint

$\mathrm{X}$

Preface to the First Edition

xii

\section{PART I AMERICA AND THE WORLD}

1 Incentives for Analysis 3

First Efforts 3

Three-way Analysis $\quad 5$

Carter and Reagan $\quad 11$

Familiar Institutions $\quad 14$

Foreign Relations and Human Relations 18

Diversity 21

American Foreign Policy 24

Implications for the USA 28

2 A Reagan Revolution? 30

A Reagan Style 'Revolution' $\quad 30$

Patterns of Continuity 33

The Race for the White House 36

Military Priority 40

Star Wars Power 41

Tensions with Europe $\quad 43$

Middle East Adventure and Disaster 45

Relentless Economics - Trade and Finance 47

Re-Election 48

Second Term and Iran-Contra 50

Detente Revisited 53

Evaluation of Reagan $\quad 54$

Reagan and the Public $\quad 58$

3 Asia and Europe, Emergence and Change 62

Bush: Failure to Inspire $\quad 63$

Cohesive, Collegial Style $\quad 66$

The Gulf War 68

Europe: Unity, Disunity and 1992

Germany: Unification $\quad 71$

The Eastern Bloc $\quad 73$ 
$\begin{array}{ll}\text { Japan: Frustration } & 75\end{array}$

Clinton: Foreign Policy Unfolding $\quad 78$

Europe: Balkan Quagmire $\quad 79$

Nato: Durable, Expandable $\quad 82$

Asia: APEC, China, Japan $\quad 82$

Conceptual Frameworks Past and Present $\quad 85$

The Eye of Presidential Politics $\quad 86$

$\begin{array}{ll}\text { The State of Opinion } & 87\end{array}$

Communication Beyond Polls $\quad 89$

\section{PART II FOREIGN POLICY AFTER THE COLD WAR}

4 Soviet Collapse, World Disorder $\quad 93$

Cold War and After 93

Soviet Theory, Soviet Practice 95

Containment Vindicated 96

Beyond Containment 97

Leaders and Goals $\quad 98$

Structures of Alliance $\quad 100$

European Union and Disunion 106

Europe 1992: Success, Failure, Uncertainty 109

Asia 110

Change in International Relations 115

Germany and Japan 118

Britain and Korea: Diplomats, Traders, Warriors 119

South Korea: Economic and Political Miracles 126

Partners in War 129

After Communism and Fascism 131

5 An American Worldview; An American World 134

National Interest and International Community 134

Democracy and Markets 135

Ideology and Liberalism 139

Structure - Nato: Arms and Influence 142

European Union: Commerce and Finance 147

The 'Private Sector' on the World Stage 149

People 150

An American Worldview: An American World 153

Security Threats, Policy Challenges 157

Public and Private 157 
Epilogue to the 2000 Reprint: The Indispensability of Leadership 162 Notes 174

Bibliography 190 Index 205 


\section{Preface to the 2000 Reprint}

The publication of an updated edition of After the Cold War: American Foreign Policy, Europe and Asia has provided a welcome opportunity to review and reflect upon the volume. I believe the basic themes and contours of the study have stood up well, at least over the short term of the several years since the manuscript was completed in 1996. Certainly the steadily growing importance in contemporary international relations of both the mass media and the private commercial realm has been confirmed. The spread of both representative democracy and relatively open competitive markets has now reached a point where any broad global reversal of the trend is difficult to conceive.

Very different, however, is the view, especially popular currently in the United States, that the business cycle and recessions have been abolished and that - by implication - the world has somehow become relatively easy to manage. The difficulty of perceiving emerging problems on the horizon of policy, especially in the midst of a relatively stable and extremely prosperous age, underscores the basic challenge confronting leadership at the national level and for that matter other levels, including not only multinational corporations but virtually all organizations, large and small. Anticipating surprise, or even the full implications of partially anticipated developments, is at the heart of successful leadership, whether the chief executive attempting to guide a nation or the individual attempting to manage a career. After literally decades of anxiety, combined with periods of outright fear, the Cold War has been replaced by an era in which complacency, excessive self-confidence and occasional hubris encourage misperception and miscalculation. President Bill Clinton, in his selfindulgence and self-righteousness, personifies this era to an unnerving degree. The crucial variable of leadership, therefore, is emphasized in the Epilogue as in the original body of the text.

From high policy to immediate work environment, Carthage College in Kenosha Wisconsin has provided a most congenial environment for reviewing and updating this work. Initial contacts with President F. Gregory Campbell and Dean Kurt Piepenberg were followed by a series of conversations with other administrators, faculty and staff, concluding in appointment in April 1998 as the A.W. and Mary Margaret Clausen Distinguished Professor of Political Economy and World Business. Alden W. 'Tom' Clausen is former Chairman and Chief Executive Officer of Bank of America as well as President of the World Bank. He and his wife Peggy 
have very generously supported student scholarships as well as the academic chair I occupy at the College. After years in nonprofit administration, involving helping to build the Chicago Council on Foreign Relations and a successful turnaround of a nearly bankrupt World Trade Center Association, a change of context was very much in order. The honest, warm and friendly community at Carthage provides an ideal setting for effective teaching as well as sustained scholarship.

Continuing involvement with the Chicago Council on Foreign Relations, where I worked for many years, has also been a source of professional insight as well as substantive information useful to this study. My friend John E. Rielly, President of the Council, asked me to participate in the 1999 edition of the Council public opinion report. Information from that publication is highlighted in the Epilogue. Working to build an effective educational and service organization over a long period of time has been a source of very great satisfaction as well as a worthwhile professional experience, and I appreciate the opportunity to continue involvement there.

A new edition of the book provides an opportunity as well to acknowledge individuals not previously mentioned. Professor David E. Bell of Harvard University provided an outstanding professional example years ago at the Ford Foundation, following his service as Director of the Bureau of the Budget in the Kennedy administration and later as Director of the U.S. Agency for International Development in the Kennedy and Johnson administrations. Several years ago, he was a source of very helpful, insightful advice on what to do - and what to watch out for - in the vortex of strengthening a troubled world trade association. Any individual worth mentioning should have integrity; Dave fulfils this requirement to a remarkable degree. The role of nongovernmental organizations in mediating between the public and private sectors is one I hope to develop at greater length in a succeeding volume. During the past several years, I have been fortunate to continue involvement with the Ditchley Park program, thanks to the good will of Director Sir Michael Quinlan and Deputy Director Heather Weeks in England and Administrative Director John J. O'Connor in the US. Ambassador Hong-koo Lee of the Republic of Korea in Washington DC, as well as Consul General Jong Kyou Byun in Chicago, have been very helpful, especially in increasing the visibility of the volume in their country. Consul General Michael Hodge of Great Britain in Chicago likewise has helped round out ideas for this updated edition.

Finally, my three sons - David, Tom and Jay - have provided welcome companionship and in each case a good example of the importance of sustained focus in accomplishing a goal. 


\section{Preface to the First Edition}

The genesis of this book has been my long-term fascination with the interplay of domestic and international factors in the development and conduct of foreign policy, plus work on international affairs and politics in Europe and, more recently, Asia. The revolutionary developments in the international system in recent years have provided rich material for analysis; there is a challenge simply to understand what has been happening as great powers have both collapsed and reunited. Likely consequences of the end of the Cold War and the implications for leaders in the United States, and elsewhere, inform the discussion in these chapters. The collapse of the Soviet Union, the unification of Germany, the end of the Cold War as a diplomatic and military competition, the related failure of communism as a secular religion, and other developments have profoundly altered the social and intellectual as well as political atmosphere and landscape of international relations. No single volume, even a much longer one, could possibly fully analyse all of these changes, and my own hope is that this particular perspective or 'take' on these events will encourage debate and discussion in policy and scholarly circles as well as being of interest to the general public.

Even in a revolutionary period, important elements of continuity can be found. The nation-state is still the basic unit of the system, and particular allies of the United States are worth special attention in addressing a world which we cannot, and never could, manage alone. Despite the great changes which have occurred, Europe remains the principal source of the cultural heritage of the United States, including our political practices and institutions. We maintain a relationship with Britain that transcends and endures beyond passing disagreements over policy, the economic and imperial decline of the older power, and the vagaries and unpredictability of democracy in both nations, especially our own boisterous political arena. For these reasons, and also because of a history of exceptional diplomatic experience and skill, Britain is given special attention in the course of this volume as a nation with lessons for others in the post-Cold War world.

Asia provides a dimension for comparison and also a region that can no longer be neglected in discussing political as well as economic influences on America, Europe and Atlantic area relations generally. To some extent, this has of course always been true. A classic old cartoon in the New Yorker showed two prosperous middle-aged couples, in evening dress and 
immersed in social chit chat. One smug gentleman is saying that the other is forgetting one thing in his remarks: '... Asia'. Only the fatuous would ignore, or underestimate, the impacts of this enormous region. However, only in recent years have Asian nations beyond Japan become notable engines of industrial development along with traditional roles as sources of raw materials. In an earlier era plausible analysis could deal pretty exclusively in geographic terms with Atlantic area nations alone. During the height of the Cold War, we were concerned with Asia primarily in military security terms with the perceived threat of 'Red' China, wars in Korea and Vietnam, a Soviet-American arms race that was global innature, and other related developments. Asia today is leading economic growth in the world, becoming more democratic, and undercutting earlier ideological and imperial divisions.

The Republic of Korea receives special emphasis for several reasons. The success of South Korea has been spectacular in vaulting over a short period of time from very low income and economic underdevelopment to become a powerhouse of productivity and commercial effectiveness. This success has in very recent years been married to transition from dictatorship to representative democracy. The Korean War cemented our special relationship with that country, whereas histories of Cold War as well as war still create some distance between the United States and the other great powers of Asia, China and Japan.

This book is not designed exclusively for those who concentrate on international relations but also for the interested general reader; a principal ambition in fact is to provide a sort of handbook or outline to assist thinking and reading about unfolding American foreign policy in regard to Asia, Europe and in general. The Notes section is designed to provide useful background and suggestions for further reading to the serious generalist. The same ambition is reflected in a relatively comprehensive bibliography. The current world involves a new interplay between traditional diplomacy and a drastically changed international system, dramatic growth in public participation and involvement in foreign affairs, the influence of interests previously seen as largely or wholly domestic, and pervasive electronic media providing instant information - both true and false, accurate and inaccurate. Revolutionary doctrines of communism and fascism have been defeated, democracy is more widespread than ever in history, and international relations are being transformed. Communication between specialists and generalists in consequence is of high priority.

I am indebted to a number of individuals for advice, commentary and insight. Some have read parts of the manuscript. Most have been helpful over the years in more informal conversation and interchange, in some 
cases simply by providing the right sort of example concerning how to go about serious research and analysis, especially in an age when specialized divisions of labour, pressured schedules and pervasive media all encourage a superficial approach to the great matters of our time. They include among faculty professors William James Adams of the University of Michigan, Byung-joon Ahn of Yonsei University in South Korea, McGeorge Bundy of New York University, Bruce Cumings of Northwestern University, Lawrence Freedman of the University of London, Jonathan Galloway of Lake Forest College, Charles Glaser of the University of Chicago, Roy Grow of Carleton College, Donald Haider of Northwestern University, Russell Hardin of New York University, D. Gale Johnson of the University of Chicago, B.C. Koh of the University of Illinois, Edward Kolodziej of the University of Illinois, Andrzej Korbonski of UCLA, Richard Kosobud of the University of Illinois, Ho-Youn Kwon of North Park College, Phyllis Lyons of Northwestern University, Peter Merkl of the University of California at Santa Barbara, Joseph Nye of Harvard University, Benjamin Page of Northwestern University, Stephen Szabo of the School for Advanced International Studies in Washington DC, and Charles Wolf of the Rand Graduate School.

Others generous with advice and assistance have included Tom Boodell of Rudnick and Wolfe, Lord Carrington, Dr Gary Geipel of the Hudson Institute, President Noboru Hatakeyama of the Japan External TradeOrganization in Tokyo, former Prime Minister Duck Woo Nam of South Korea, Executive Vice President Russell Phillips of the Rockefeller Brothers Fund, Dr John Steinbruner of the Brookings Institution, Dr John Stremlau of the Carnegie Corporation, and Dr Francis X. Sutton of the Ford Foundation and a whole array of non-profit and service organizations. Sir John Graham, Director of Ditchley Park in Oxford and his predecessors, along with Charles Muller of the American Ditchley Foundation, have provided a wonderful opportunity over the years to examine the Anglo-American relationship in fine style.

Professor Samuel H. Beer of Harvard University more than any other single individual set me on the right road of scholarship many years ago and has remained a valued and wise friend as well as mentor.

Professor George Yu, Director of the Center for East Asian and Pacific Studies at the University of Illinois at Urbana-Champaign, has become a friend as well as collaborator in directing an ambitious project of the Chicago Council on Foreign Relations on American foreign policy in Asia after the Cold War. Participating with him and the other authors in that project has contributed greatly to my education on Asia. Mr. T. M. Farmiloe of Macmillan has over the years been exceptionally receptive to both ideas 
and manuscript, and understanding as well concerning unexpected delays and changes. His courtesy and professionalism set a fine example.

Work at the Chicago Council on Foreign Relations has provided a foreign policy education and the experience of general public education beyond the college and university world. I have appreciated collaborating with Council President John E. Rielly on the public opinion reports cited in the text, the Atlantic Conference series which he directs, the Asia project cited just above, and all the other matters great and small associated with our work together in building one particular institution. Any effective organization is more than one or two individuals, and other colleagues at the Council over the years have contributed, each in a helpful way.

All these people contributed in a helpful, positive, often very distinctive way, to my efforts to bring Asia and Europe together within analysis of American foreign policy. 